\title{
USING FORECASTS IN DEVELOPERS INVESTING ACTIVITIES
}

\author{
Daniel Salachna, M.Sc. \\ Wroclaw University of Economics \\ e-mail:daniel.salachna@o2.pl
}

\begin{abstract}
The number of future sales of residential real estate in the primary developer depends mainly on the factor of demand, consumer needs for housing in established market conditions. One way to determine the future market capacity for the construction of residential demand forecasts.

The company is in a very favorable position, having a reliable forecast of future demand. Forecast has an impact on the ability to achieve the intended purpose of building and as a result allows you to minimize the risk of return on invested capital at the same time ensuring a profit.

Placed forecast future sales of apartments in the time horizon of two years in advance, taking into account a series of standardized construction, contains processed numerical data on a quarterly sale by $\mathrm{X}$ developer in the years from 2008 to 2012.

Erected on the basis of forecast model and found very useful model to predict seasonal fluctuations in demand numerical sale in the test development company.
\end{abstract}

Keywords: forecast, developer, investing.

JEL Classification: R21.

Citation: Salachna D., (2013), "Using forecast in developers investing activities", Real Estate Management and Valuation, vol. 21, no. 1, pp. 32-38.

DOI: 10.2478/remav-2013-0005.

\section{Introduction}

The real estate market, both global and domestic, undergoes many changes over the years. The dream of owning your own house or apartment, however, is still valid.

Immediately after World War II housing in Poland was very inefficient and did not kept up with rising demand. The pioneers of the then-market housing were housing associations that specialized in building affordable flats with an average area in apartment buildings, mostly for the needs of the middle class. In the years 2000 - 2006 there was a significant increase in multi-family completions of residential buildings, usually located in gated housing estates (DZIWORSKA 2007).

For families the desire to have their own flats was not only a dream, but also the guarantee of the increased social status. This trend prevailed until mid-2007. A characteristic feature of the real estate market in recent years was a significant excess of demand over supply, due to the easy access to mortgages. In the second half of 2007 the nationwide demand trend was decisively curbed and decreased markedly. This situation has not changed to this day, although the supply of housing still remains at a high level.

The aim of the study was to show, for example, to the developer the place of forecasts in decisionmaking venture investment.

\section{The real estate market}

The real estate market seen in economic terms is generally an interchangeable relationship between sellers - representing supply, and buyers, who report the need for a purchase of goods, which are houses offered in the property market (KUCHARSKA-STASIAK 2004). The real estate market can also be 
defined as the totality of relations that may exist between the sellers, reporting the real estate market offers, and the investors.

Considering the housing market in spatial terms, you can define it as a market of both local and global range. In fact, every housing market is a local market, limited due to the inability to transfer the property to another location. The property, even from the international or global market never loses its locality features and, therefore, market capacity is most recognizable by local developers.

Unique characteristics of housing such as the stability of place, variety and durability make the competition always has a local character. Every local real estate market, however, is different, has different needs and, at the same time, creates different requirements and meets the diverse tastes of customers. The housing market is unique due to the fact that each property is located in a certain environment. Furthermore, considering the long-time associated with a standardized construction, it is also not very flexible.

The housing market provides full freedom to determine supply and demand. As a result, decisions to buy houses are very thoughtful. Buyers taking into account the fact that the purchase of real estate is usually a long-term investment, contribute to the fact that supply and demand in the local real estate market usually varies seasonally. The change in supply and demand for real estate is also influenced, by the state intervention through financial involvement that might increase, and supply especially in the national housing market.

The development of the real estate market has contributed to the emergence of new players on the market as sellers, in the case of new dwellings. A special place among the participants in the primary real estate market is held by development companies. The high capital intensity of the undertakings (different investment projects - construction) of primary real estate market makes it the largest investors in this market are traders operating in the construction sector, so called "Developers". It should also be noted in this investment is a capital expenditure which is expected to bring specific property or financial results in an established period of time.

The real estate market including housing is primarily shaped by important stakeholders in the real estate market, which are existing companies connected with the development sector, operating in a new segment of the housing market. The activities of the developer seems to be the most complex form of investment in real estate, especially housing and their disposal. The developer shall prepare and implement an investment project in the housing market, both in terms of formal, technical as well as financial aspects, and then place it on the market.

A developer deciding to implement measures to increase the supply of housing, must anticipate and take into account the potential risks and uncertainties associated with competitors, buyers, government policy, progressive technology, economic factors, social and demographic trends. Defining the term of risk it is assumed that this is a project whose outcome is unknown and uncertain, with no guarantee of success.

Between the participants of the development process (diagram 1), who tend to have different expectations of the project there are certain relationships. Investments in real estate are capitalintensive, require a substantial cash contribution, the funding from foreign sources, mostly loans granted by banks which participate in financing the project and may play a dual role - lenders and investors. The developer and the investor are an inseparable pair in the property market, the first provides the final draft, and the other is the receiver for the sale of the expected effect.

The commodity in the real estate market is rights. The most important is the right of the property ownership. In the market economy it is assumed that the meeting market players, i.e. the seller (representing the supply side) and the buyer (representing the demand side), making the transfer transaction, try to maximize it. Both of these entities are free activities, including decision-making. Sellers also obtain information on what houses are particularly sought after, which will be offered for sale now or in the future. In the real estate market there is an asymmetry of information, due to the fact that the developer has a greater knowledge of the flats and houses sold than the potential buyer. So in the case of any other good (product) the knowledge about an offered property can be very diverse. Developers are high-class professionals, who not only have the knowledge of the construction industry and new technologies, but are also great negotiators and psychologists. With complete knowledge about an apartment or house to sell, they share with buyers only that information which increase the chances of selling the property. 


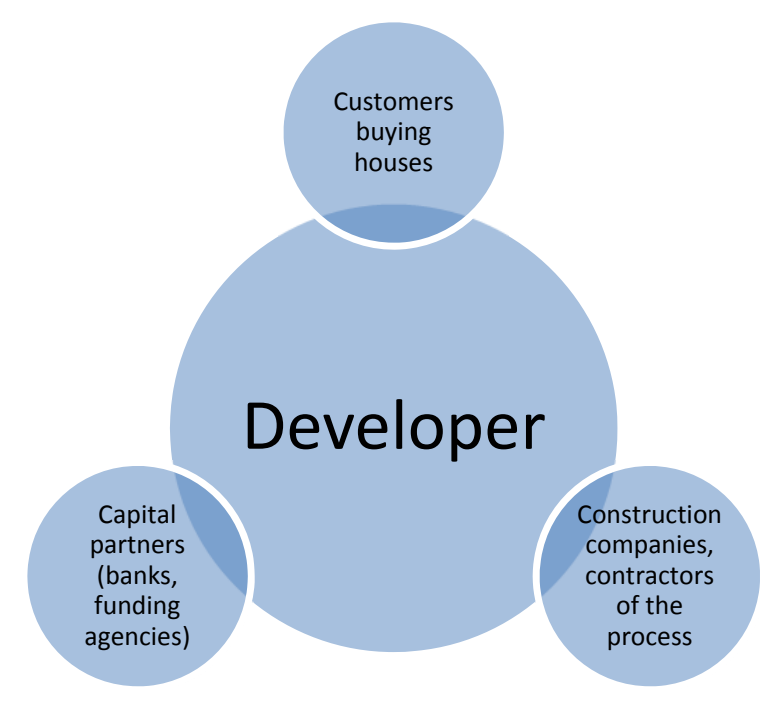

Diagram 1. The developer and the participants of the investment process. Source: own study.

\section{The diagnosis of the real estate market absorption}

One way to determine the absorption of the future real estate market is to build demand forecasts.

Forecasting is a prediction of future events, and its aim is to minimize the consequences of the possible risk of making wrong decisions (DITTMANN 2010). So forecasting is the art of predicting the behavior of buyers, the future state of the local market, and the relationship of supply in the area of real estate development company. The real estate market is generally perceived and assessed through the prism of concluded sales contracts. The number of transactions of housing disposing depends primarily on the number of dwellings for which the buyer is sought. Developers usually offer to sell apartments at the turn of the third and fourth quarter. The End of the year is usually the time of silence in the housing market and the revival takes place only at the beginning of the new year. In the first quarter of the new year there are houses sold the previous year.

The modern real estate market including residential real estate, is a key area in terms of higherorder needs of households, their primary and exclusive satisfaction. Statistical data confirm that there were the periods of (2003 - 2006), in which the demand exceeded the supply of housing, interspersed with periods in which the situation was the opposite. Table 1 shows CSO forecast of demographic growth rate of households in Poland by 2022.

Table 1

Forecast number of households

\begin{tabular}{lcc}
\hline Year & Households & Increase in the number of households \\
\hline 2010 & 14600014 & 135482 \\
\hline 2012 & 14831271 & 108477 \\
\hline 2014 & 15009467 & 83312 \\
\hline 1016 & 15138018 & 58642 \\
\hline 2018 & 15220932 & 37248 \\
\hline 2020 & 15259514 & 14161 \\
\hline 2022 & 15272408 & 2078 \\
\hline
\end{tabular}

Source: own study based on CSO demographic projections.

The analysis of the above data may indicate that the demographic change will cause developers to force companies to greater efficiency in the search for solutions to increase the propensity of customers in respect of the acquisition of apartments in the primary market. In addition, the progressive depopulation of the population in future years may determine the phenomenon of saturation of demand for housing, and not only in the primary market. 


\section{Empirical example}

In this paper, the study concerns the primary real estate market in the town of $\mathrm{Y}$. The study subjects were the purchase-sale transactions of residential property from a developer $X$ within five years (20072012). The aim of this paper is to analyze and evaluate the quantitative dynamics of the purchase sale transaction of residential real estate from the company, without the impact of the price factor. The issue of pricing for suburban, local market is not the subject of the study. The paper presents a partial implementation of the project in an important, hitherto known, stable environment with a convenient location, with good public transport access in different socio - economic conditions. The project is carried out within two years, which is why the developer should be certain of already existing conditions accompanying the completion of the investment. If it requires a long time the risk of the project increases. The stage analyzed herein is the continuation of an earlier investment, while maintaining the same location, the structure of the object corresponding to the market demand of future owners sought. Source materials that form the basis of the research come from the developer and it is the recorded sales of dwellings started and completed in the last 60 months.

Table 2

Number of homes sold by developers in the years 2008 - 2012

\begin{tabular}{|c|c|c|c|c|c|}
\hline \multicolumn{2}{|c|}{ Term } & $Y$ & \multicolumn{2}{|c|}{ Term } & $Y$ \\
\hline \multirow{4}{*}{2007} & I & 33 & \multirow[b]{2}{*}{2009} & III & 61 \\
\hline & II & 51 & & IV & 73 \\
\hline & III & 61 & \multirow{4}{*}{2010} & I & 32 \\
\hline & IV & 74 & & II & 54 \\
\hline \multirow{4}{*}{2008} & I & 35 & & III & 67 \\
\hline & II & 49 & & IV & 79 \\
\hline & III & 58 & \multirow{4}{*}{2011} & I & 38 \\
\hline & IV & 71 & & II & 51 \\
\hline \multirow[b]{2}{*}{2009} & I & 31 & & III & 57 \\
\hline & II & 52 & & IV & 73 \\
\hline
\end{tabular}

Source: own study based on data from real-estate development company.

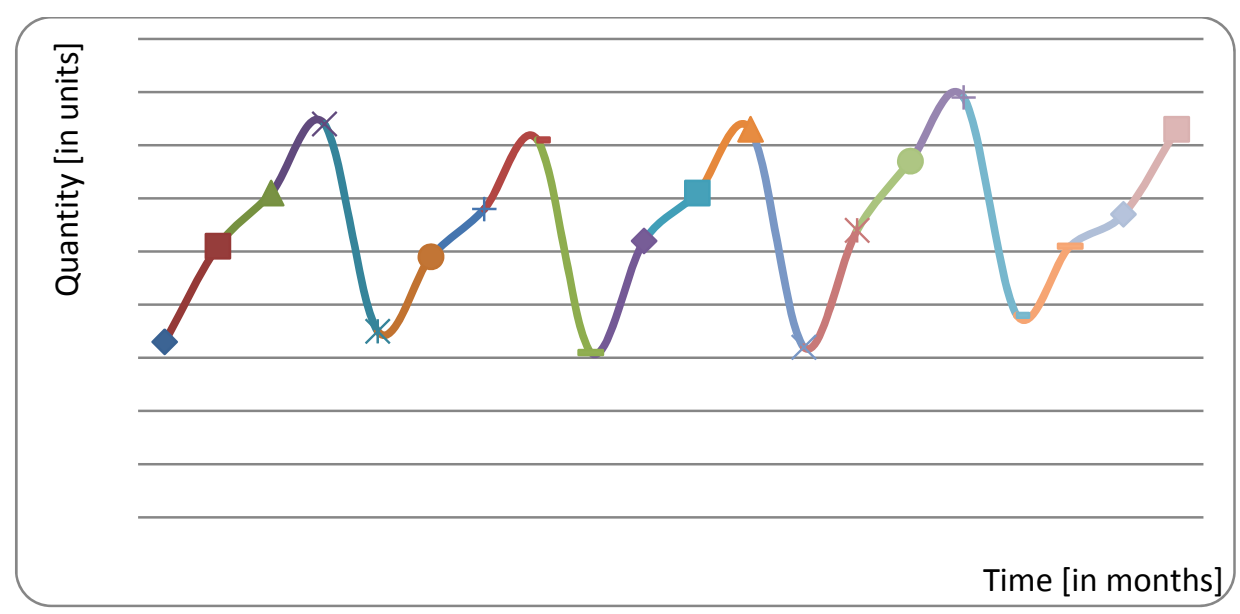

Diagram 2. Number of homes sold by the developer. Source: own study based on data from table 2.

Based on the diagram and made the analysis of variance (table 3) it can be seen that the sale occurs seasonally. Therefore, sales analysis and forecast construction uses an additive model of seasonal fluctuations.

The model of the prediction sale of $X$ development company dwellings for the data in table 2 assumes the following form

Seasonal factors $\left(w_{j}\right)$ trend function

$$
y_{T_{l j}}^{*}=-0,6 T+61,33+w_{j}
$$


Table 3

Analysis of variance

\begin{tabular}{ccccccc}
\hline Source of Variation & $S S$ & $d f$ & $M S$ & $F$ & P-value & F crit \\
\hline Rows & 8711.329 & 19 & 458.491 & 37.45417 & $3.39 \mathrm{E}-11$ & 2.168252 \\
\hline Columns & $1.82 \mathrm{E}-12$ & 1 & $1.82 \mathrm{E}-12$ & $1.49 \mathrm{E}-13$ & 1 & 4.38075 \\
\hline Error & 232.5864 & 19 & 12.24139 & & & \\
\hline Total & 8943.916 & 39 & & & & \\
\hline
\end{tabular}

Source: own study.

Table 4

Seasonal factors

\begin{tabular}{cc}
\hline Quarter & $\begin{array}{c}\text { Seasonal } \\
\text { factors }\end{array}$ \\
\hline 1 & -22.10 \\
\hline 2 & -3.90 \\
\hline 3 & 6.10 \\
\hline 4 & 19.90 \\
\hline
\end{tabular}

Source: own study.

The forecast for four consecutive quarters of the year 2013 assumes the following numerical values:

- $\mathrm{T}=21$, for the first quarter of 2013 years $=27$

- $\mathrm{T}=22$, for the second quarter of 2013 years $=44$

- $\mathrm{T}=23$, for the third quarter of 2013 years $=54$

- $\mathrm{T}=24$, for the fourth quarter of 2013 years $=67$

The actual and estimated on the basis of the constructed model data are shown in diagram 3.

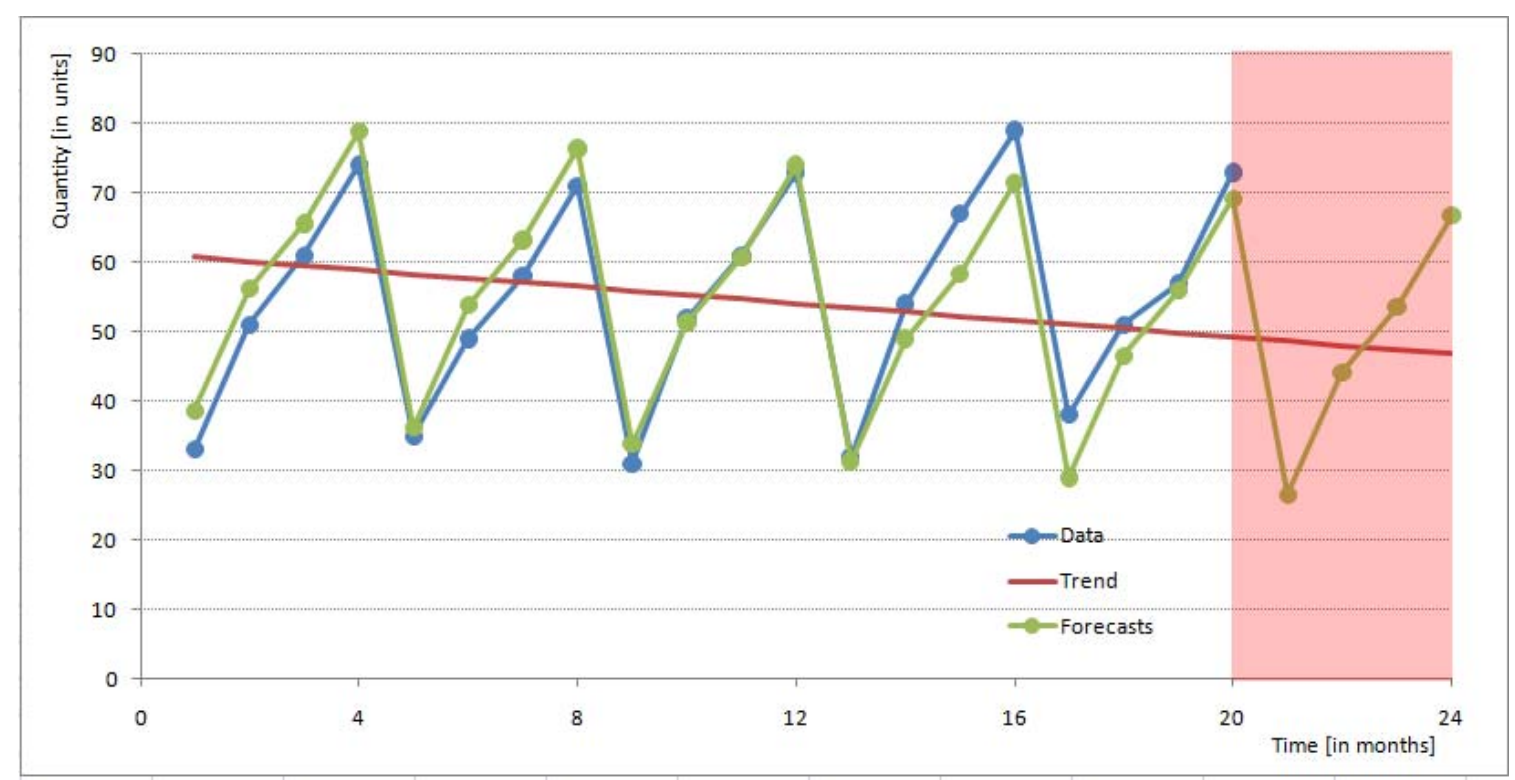

Diagram 3. Actual estimated data. Source: own study.

Analysing the data presented in the graph it can be concluded that in the period 2008 - 2012 the size of houses sold was almost equal to the sizes estimated. It is therefore assumed that the constructed model may be used to build a prediction for the next period. The expected number of dwellings sales in 2013 amounted to 192.

The numerical value of forecasts, may constitute an explanation of the variability of demand. After the high growth in demand - held for several years, the projected demand is decreasing, its value is lower. Executed forecast meets the expectations of a development company in the relation to 
the demand for new apartments and it will a how to sell the product with success. The number of quarterly sales is similar, but the developer wants to get information on the expected sales in the next year. The company may adjust its operations to the forecasts and make changes if demand drops. The forecast shows a downward trend, which may mean fading market for these products.

With regard to the presented scenario forecasts it can be seen that the greatest effect on the dynamic going down the developer's of investment has the unit number of sold houses and the time of the transaction. These relationships with the assumption that they are dependent on each other, are processed together. Offers of unit housing quantities and unit transaction prices are shown in table 5.

Table 5

Calculation of expected profits

\begin{tabular}{lc}
\hline Year & $\mathbf{2 0 1 3}$ \\
\hline Number of flats & 192 \\
\hline The total usable floor space in $\mathrm{m}^{2}$ & 9500 \\
\hline Selling price of apartment in PLN $/ \mathrm{m}^{2}$ & 6000 \\
\hline Number of parking spaces & 119 \\
\hline Selling price of parking space in PLN & 15000 \\
\hline No mortgage payments & 0 \\
\hline
\end{tabular}

Source: own study based on GAWRON (2011).

The analysis of financial results shows that the adopted assumptions shown in table 5 can give a total amount of 74850000 PLN, which will cover the construction cost value and profit founded by the developer of the project.

\section{Summary and conclusions}

The forecast presented in this paper represents, a variant of various implications of the use of the past to measure future demand in a development company's forecasting process.

An example of an empirical theory acknowledges clearly reduced demand for the next four quarters. Future sales in business practice for newly built dwellings are limited by demand issues (finding buyers) rather than the supply. Reevaluation and adoption of an incorrect forecast of demand will be linked to the lack of customers and incurring losses on the part of the developer. Table 6 shows the simplified calculation of expected expenses to run out of the investment.

Table 6

A simplified calculation of the expected spending to run out of the investment

\begin{tabular}{lc}
\hline The monthly cost of building management PLN/m $\mathrm{m}^{2}$ & 4 \\
\hline Annual property insurance PLN/m ${ }^{2}$ & 5 \\
\hline Monthly operating costs PLN/m ${ }^{2}$ & 3 \\
\hline Freezing of capital invested PLN $/ \mathrm{m}^{2}$ & 6000 \\
\hline
\end{tabular}

Source: own study based on GAWRON (2011).

The prospect of the development of housing - ready apartments in the local markets in the country definitely will depend on market and non-market factors and demand. Therefore, developers must constantly predict future demand to know the available forecasts, in particular those relating to population change population and households, and on this basis to plan and carry out an economic activity. The phenomenon of demand can behave differently depending on the number of buyers sought, the standard and the market trends and economic situation of the country.

\section{Bibliography}

CIEŚLAK M..., 2005, Prognozowanie gospodarcze metody $i$ zastosowanie, Wydawnictwo Naukowe PWN, 2005, Warszawa.

DitTMANN P., SZABElA - PASIERBIŃSKA E., DitTMANN I., SZPUlAK A., 2005, Prognozowanie w zarządzaniu sprzedaża i finansami przedsiębiorstwa, Oficyna Wolters Kluwer Business, Warszawa.

DZIWORSKA K., GEUSTS T., LORENS P., 2007, Strategie inwestowania w nieruchomości, URBANISTA, Warszawa. 
GAWRON H., 2011, Metody opłacalności inwestycji na rynku nieruchomości, Wydawnictwo Uniwersytetu Ekonomicznego w Poznaniu, 2011, Poznań.

KUCHARSKA - STASIAK E., 2004, Nieruchomości a rynek, PWN, 2004, Warszawa. 